et al., 1969) and by leakage of iodide-like material from the gland (DeGroot, 1966).

One must consider the significance of long-standing diets high in iodide. In Tasmania the addition of iodate in the bread-making process was followed closely by a pronounced increase in the incidence of thyrotoxicosis (Vidor et al., 1968). Thyrotoxicosis has been induced by supplementing the diet with as little as $1.5 \mathrm{mg}$ of iodide daily over the course of a few weeks, and after treatment with iodized oil injection. This phenomenon has been reported only in areas of endemic goitre. The possibility of an increased incidence of thyrotoxicosis due to high iodide intake in areas without endemic goitre is present, though this possibility was considered unlikely (Stanbury, 1969).

Immediate disadvantages of high iodide intake are principally concerned with the administration of radioiodine for scanning and uptake studies. The lower thyroidal uptakes make it necessary to administer higher doses of ${ }^{131} I$ for scanning and uptake studies to maintain quality, which results in more radiation delivered to the thyroid and whole body. In addition, larger therapeutic doses of radioiodine for thyrotoxicosis and thyroidal ablation also are necessary. A less commonly encountered disadvantage of high iodide intake occurs in patients with functioning metastases from thyroid cancer. It is likely that high dietary intake of iodide would result in diminished ${ }^{131}$ I uptake by functioning metastases, thereby limiting the efficacy of radioiodine therapy in this disorder.
It would seem useful to have a "local factor" for each community which could be used in comparing radioiodine uptakes from one area to another. For example, if the Bronx range was regarded as 1 , the Columbia factor would be $0 \cdot 4$. In this manner reported results could be readily adjusted for comparison.

Send reprint requests to: Dr. Bernard A. Sachs, Montefiore Hospital and Medical Center, 111 East 210th Street, Bronx, New York 10467, U.S.A.

\section{References}

Barker, S. B., Humphrey, M. J., and Soley, M. H. (1951). fournal of Clinical Investigation, 30, 55

Caplan, R. H., and Kujak, R. (1971). Fournal of the American Medical Association, 215, 916 .

DeGroot, L. J. (1966). Fournal of Clinical Endocrinology and Metabolism, 26, 149.

London, W. T., Vought, R. L., and Brown, F. A. (1965). New England Fournal of Medicine, 273, 381 .

Oddie, T. H., Fisher, D. A., McConahey, W. M., and Thompson, C. S. (1970). Fournal of Clinical Endocrinology and Metabolism, 30, 659 .

Pittman, J. A., Dailey, G. E., and Beschi, R. J. (1969). New England fournal of Medicine, 280, 1431.

Saxena, K. M., Chapman, E. M., and Pryles, C. V. (1963). Science, 138, 430.

Stanbury, J. B. (1969). New England fournal of Medicine, 280, 1474

Vidor, G., et al. (1968). Australasian Annals of Medicine, 17, 162.

\title{
Kidney Function after Methoxyflurane Analgesia during Labour
}

\author{
MICHAEL ROSEN, P. LATTO, A. W. ASSCHER
}

\section{Introduction}

Several reports of nephrotoxicity following prolonged methoxyflurane anaesthesia have been published (Crandall et al., 1966; Frascino et al., 1970; Mazze et al., 1971). Present views tend to favour a dose-dependent toxicity (Vandam, 1970; Mazze et al., 1971; Committee on Anesthesia, 1971). In Great Britain methoxyflurane has, after extensive trials, been approved by the Central Midwives Board for use as a self-administered inhalation analgesic during labour (Major et al., 1966; Jones et al., 1969; Rosen et al., 1969). In some 3,000 obstetric patients who had received methoxyflurane, anaesthesia renal complications were not observed (Lapointe and Bele-Binda, 1970). Nevertheless, even with the lower concentration used for analgesia some doubt might exist whether tubular dysfunction occurs in these circumstances. The present studies were designed to investigate this.

had nitrous oxide analgesia, the urinary and blood urea concentrations were measured on the morning of discharge from hospital. There were no significant differences between the groups. These results suggest that methoxyflurane is not nephrotoxic when used as a selfadministered analgesic.

University Hospital of Wales, Royal Infirmary, Cardiff CF2 1SZ

MICHAEL ROSEN, F.F.A. R.C.S., Consultant Anaethetist

P. LATTO, F.F.A. R.C.S., D.A., Senior Registrar in Anaesthetics

Medical Unit, Welsh National School of Medicine, K.R.U.F. Institute of Renal Disease, Royal Infirmary, Cardiff

A. W. ASSCHER, M.D., F.R.C.P., Reader in Medicine
One study was undertaken to examine tubular function in some detail before and for some days after methoxyflurane inhalation, and another to screen a larger group of mothers. Since renal function tests after delivery may be difficult to interpret the mothers who had methoxyflurane were compared with others who had nitrous oxide, which has not been implicated as a nephrotoxic agent.

The first study, in one obstetric unit, included 50 mothers delivery. These patients were randomized with regard to the

\section{Method} judged by the midwife as requiring inhalation analgesia for 
analgesic used. On alternate weeks either methoxyflurane $0.35 \%$ (Cardiff Penthrane Inhaler) or $50 \%$ nitrous oxide and $50 \%$ oxygen (Entonox) was administered. Specimens of urine and blood were obtained on the morning before labour. Early morning (about 06.00 hours) specimens of urine and blood were then taken on three separate days, between the first and sixth days after delivery. Five patients in the methoxyflurane group and six in the nitrous oxide group were studied on two days only. The blood and urinary urea concentrations were measured with the Technicon AutoAnalyzer (method N-1c) and the serum and urinary osmolalities by freezing-point depression with the Fiske Osmometer (Advanced Instruments Co.). Haemoglobin and packed cell volume estimations (Coulter Counter model S) were also carried out. Urinary haemoglobin was measured with a Hartridge Reversion Spectroscope. Urinary contamination with lochia did not exceed a concentration of $500 \mathrm{mg} / 100 \mathrm{ml}$. Urinary urea and osmolality measurements were therefore not corrected.

The second study was undertaken in another obstetric unit. Blood and early morning urine specimens were collected from 200 women on the day of discharge from the obstetric unit. Blood and urinary urea concentrations were measured as described above. One hundred mothers had received methoxyflurane $0.35 \%$ and 100 had $50 \%$ nitrous oxide and $50 \%$ oxygen.

\section{Results}

\section{FIRST STUDY}

The mean age of the methoxyflurane group was $26 \cdot 9$ (S.D. $\pm 7 \cdot 1$ ) years and that of the nitrous oxide group was 23.6 (S.D. \pm 5.4 ) years. There were 15 and 18 primigravidae in the two groups, respectively. The groups, therefore, are similar.

For the purpose of analysis the blood urea, urinary/blood urea ratio, serum osmolality, urinary/serum osmolality ratio, and packed cell volume estimations were grouped as shown in Table I. If more than one specimen had been taken in a period the mean of these values was used. No significant differences were found in any of the tests between the mothers who had methoxyflurane and those who had nitrous oxide (see Table II).

TABLE I-Patients Grouped According to Days on which Samples were Taken and the Inhalation Analgesic Administered

\begin{tabular}{|c|c|c|c|c|c|}
\hline & \multirow{2}{*}{\multicolumn{2}{|c|}{ Group }} & \multirow{2}{*}{ Day of Sampling } & Nitrous Oxide & Methoxyflurane \\
\hline & & & & \multicolumn{2}{|c|}{ No. of Patients } \\
\hline $\begin{array}{l}1 \\
2 \\
3 \\
4\end{array}$ & $\begin{array}{l}. \\
\cdots \\
\ldots\end{array}$ & $\begin{array}{l}\ldots \\
\cdots \\
\cdots\end{array}$ & $\begin{array}{l}\text { Before delivery } \\
\text { 1st day after delivery } \\
\text { 2nd-3rd days after delivery } \\
\text { 4th-6th days after delivery }\end{array}$ & $\begin{array}{l}25 \\
20 \\
20 \\
21\end{array}$ & $\begin{array}{l}25 \\
19 \\
21 \\
23\end{array}$ \\
\hline
\end{tabular}

Effect of Duration of Inhalation of Methoxyflurane.-For each patient the differences between her urinary/blood urea ratio and urinary/plasma osmolality ratio before delivery and the means of these ratios after delivery were plotted against the duration of inhalation of methoxyflurane. The mean duration of inhalation was $73.0 \mathrm{~min}$ (range 10-240 min). Regressions of the differences between predelivery and postdelivery ratios on the duration of inhalation were calculated. There was no significant relationship for either the urinary/blood urea ratio $(P>0.8)$ or the urinary/ plasma osmolality ratio $(P>0 \cdot 6)$.

\section{SECOND STUDY}

The choice of analgesic was left to the midwives; nevertheless the groups were comparable. The mean length of hospital stay for the patients who had received methoxyflurane was 5.3 days compared with 5.5 days for the group who had received the nitrous oxide and oxygen mixture. The mean age of the patients in the methoxyflurane group was 24.5 (S.D. \pm 5.3 ) years and in the nitrous oxide group $25 \cdot 5$ (S.D. \pm 5.9 ) years. There were 36 and 47 primigravidae in the two groups respectively.

The distributions of blood urea values and of the urinary/ blood urea ratios of the 200 patients in the two groups are shown in Figs. 1 and 2. No significant differences between the groups exist.

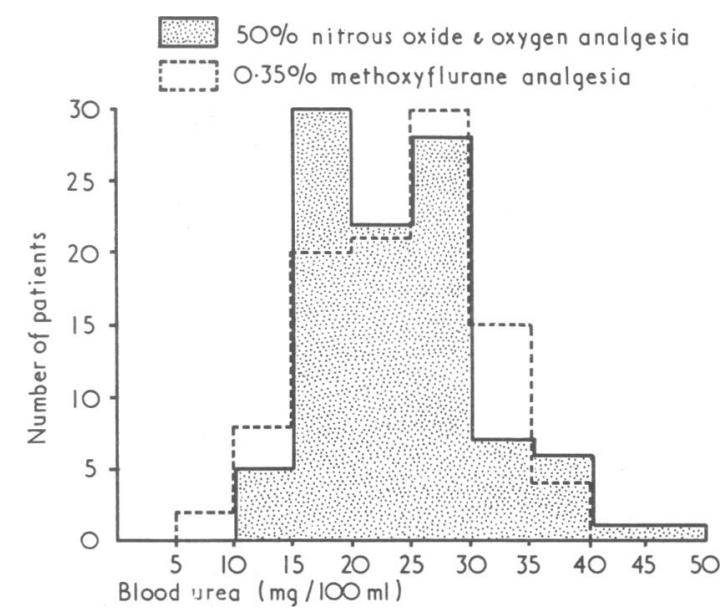

FIG. 1-Distribution of blood urea measurements on the day of discharge in 100 mothers who had $50 \%$ nitrous oxide and oxygen analgesia compared with that in 100 mothers who had $0.35 \%$ methoxyflurane analgesia.

TABLE II-Mean Values of Tests of Renal Function before and after Delivery with Nitrous Oxide and Methoxyflurane.

\begin{tabular}{|c|c|c|c|c|c|c|c|c|c|c|c|}
\hline \multicolumn{7}{|c|}{ Test } & \multirow{2}{*}{$\begin{array}{c}\text { Group } \\
1 \\
2 \\
3 \\
4\end{array}$} & \multirow{2}{*}{$\begin{array}{c}\begin{array}{c}\text { Nitrous Oxide } \\
\text { Mean } \pm 1 \text { S.D. }\end{array} \\
16.0 \pm 4.5 \\
20.0 \pm 6.9 \\
21.4 \pm 5.7 \\
21.0 \pm 5.2 \\
\end{array}$} & \multirow{2}{*}{$\begin{array}{c}\begin{array}{c}\text { Methoxyflurane } \\
\text { Mean } \pm 1 \text { S.D. }\end{array} \\
16.3 \pm 7.3 \\
16.6 \pm 5.2 \\
21.3 \pm 6.3 \\
20.8 \pm 4.4 \\
\end{array}$} & $\begin{array}{l}\text { Difference } \\
\pm \text { S.E. }\end{array}$ & \multirow{2}{*}{$\begin{array}{c}\begin{array}{r}\text { Significance } \\
\text { of Difference }\end{array} \\
>0.25 \\
>0.05 \\
>0.25 \\
>0.25\end{array}$} \\
\hline Blood Urea $(\mathrm{mg} / 100 \mathrm{ml})$ & . & $\ldots$ & $\cdots$ & .. & . & . & & & & $\begin{array}{l}-0.3 \pm 1.7 \\
+3.4 \pm 1.9 \\
+0.1 \pm 1.8 \\
+0.2 \pm 1.3\end{array}$ & \\
\hline Urinary urea/blood urea ra & atio & .. & .. & . & . & . & $\begin{array}{l}1 \\
2 \\
3 \\
4\end{array}$ & $\begin{array}{l}71 \cdot 0 \pm 22.3 \\
57.3 \pm 27.1 \\
73.4 \pm 27.3 \\
81.4 \pm 24.9\end{array}$ & $\begin{array}{l}80.8 \pm 43.2 \\
55.2 \pm 31.8 \\
70.5 \pm 28.6 \\
67.2 \pm 29.1\end{array}$ & $\begin{array}{r}9.8 \pm 9.5 \\
+\quad 2.1 \pm 9.2 \\
+\quad 2.9 \pm 8.5 \\
+14.2 \pm \mathbf{8 . 2}\end{array}$ & $\begin{array}{l}>0.25 \\
>0.25 \\
>0.25 \\
>0.05\end{array}$ \\
\hline Serum osmolality (mOsm/1 & kg) & .. & .. & .. & .. & .. & $\begin{array}{l}1 \\
2 \\
3 \\
4\end{array}$ & $\begin{array}{l}289.7 \pm 7.7 \\
288.5 \pm 7.1 \\
294.5 \pm 4.4 \\
294.7 \pm 3.8\end{array}$ & $\begin{array}{l}290.7 \pm 7.5 \\
291.8 \pm 5.7 \\
294.6 \pm 5.9 \\
295.4 \pm 5.0\end{array}$ & $\begin{array}{l}-1.0 \pm 2.1 \\
-3.3 \pm 2.1 \\
-0.1 \pm 1.6 \\
-0.7 \pm 1.4\end{array}$ & $\begin{array}{l}>0.25 \\
>0.1 \\
>0.25 \\
>0.25\end{array}$ \\
\hline Urinary osmolality/serum & osm & lity $r$ & & .. & $\ldots$ & .. & $\begin{array}{l}1 \\
2 \\
3 \\
4\end{array}$ & $\begin{array}{l}1.88 \pm 0.68 \\
1.69 \pm 0.85 \\
2.17 \pm 0.75 \\
2.22 \pm 0.59\end{array}$ & $\begin{array}{l}1.92 \pm 0.93 \\
1.49 \pm 0.62 \\
2.09 \pm 0.66 \\
2.04 \pm 0.61\end{array}$ & $\begin{array}{l}-0.04 \pm 0.2 \\
+0.20 \pm 0.2 \\
+0.08 \pm 0.2 \\
+0.18 \pm 0.2\end{array}$ & $\begin{array}{l}>0.25 \\
>0.25 \\
>0.25 \\
>0.1\end{array}$ \\
\hline Packed cell volume (\%) & . & $\cdots$ & .. & $\cdots$ & . & . & $\begin{array}{l}1 \\
2 \\
3 \\
4\end{array}$ & $\begin{array}{l}38.6 \pm 2.5 \\
38.5 \pm 4.8 \\
35.5 \pm 4 \cdot 4 \\
37 \cdot 2 \pm 3.1\end{array}$ & $\begin{array}{l}37.5 \pm 3 \cdot 1 \\
37.8 \pm 3.8 \\
34 \cdot 6 \pm 5 \cdot 2 \\
35.2 \pm 5.7\end{array}$ & $\begin{array}{l}+1.1 \pm 0.8 \\
+0.7 \pm 1.4 \\
+0.9 \pm 1.5 \\
+2.0 \pm 1.4\end{array}$ & $\begin{array}{l}>0.1 \\
>0.25 \\
>0.25 \\
>0.1\end{array}$ \\
\hline
\end{tabular}




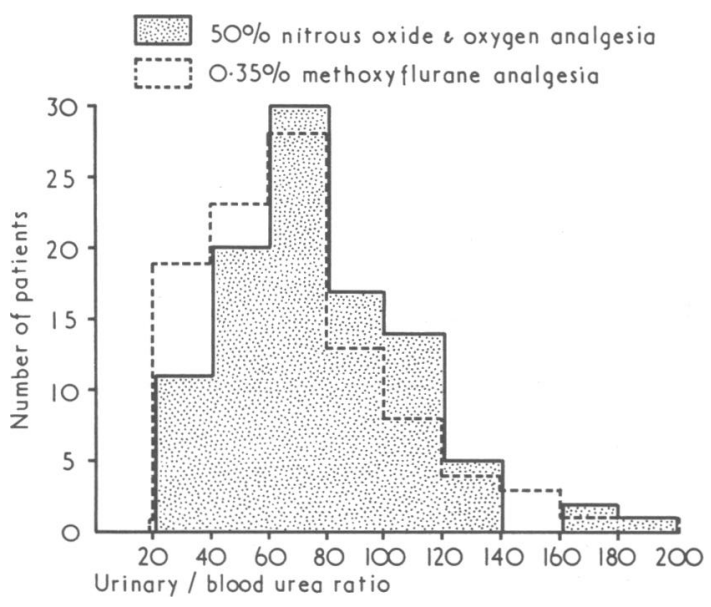

FIG. 2-Distribution of urinary/blood urea ratios on the day of discharge in 100 mothers who had $50 \%$ nitrous oxide and oxygen analgesia compared with that in 100 mothers who had $0.35 \%$ methoxyflurane analgesia.

\section{Discussion}

The published reports suggest that the nephrotoxicity of methoxyflurane is dose-dependent. Blood concentrations during methoxyflurane analgesia are about one-sixth of those attained during methoxyflurane anaesthesia (Latto et al., 1972). Even on this basis it seems unlikely on a priori grounds that obstetric analgesia would lead to any detectable renal damage.

Acute polyuric kidney failure reported after methoxyflurane anaesthesia has been characterized by inappropriate diuresis, dehydration, and increase in packed cell volume, serum osmolality, and blood urea. In the present study the urinary/serum osmolality and urinary/blood urea ratios were used to detect renal tubular damage. These tests were chosen since they do not require complete urine collections and are sensitive enough to detect acute renal tubular necrosis.

Eliahou and Bata (1965) showed that a urinary/serum osmolality ratio of 1.035 or less occurred in patients with acute renal tubular necrosis. Perlmutter et al. (1959) found that in the presence of oliguria a urinary/blood urea ratio of less than 14 indicated tubular necrosis. None of the 250 women included in the present study fell into this category consistently. In several subjects urinary/serum osmolality ratios of less than 1.035 were recorded both on the morning of the day of delivery, before either methoxyflurane or nitrous oxide had been administered, and during the first few days of the puerperium. These low ratios occurred with equal frequency among the women who received nitrous oxide and those who had methoxy- flurane. In every instance the low ratios reverted to levels of greater than 1.035 later during the puerperium. Since the effects of acute renal tubular necrosis would persist for a longer period, it seems probable that the low ratios during the puerperium are related to the excretion of excess water accumulated during pregnancy (Hytten and Leitch, 1964).

\section{Conclusions}

Though our results can never exclude minor degrees of renal tubular damage, the findings indicate that self-administered methoxyflurane analgesia does not produce the picture of acute polyuric kidney failure which has been reported following methoxyflurane anaesthesia. Nor was there any evidence that the results of the tests deteriorated with longer durations of inhalation of methoxyflurane. Furthermore, though several thousand mothers in South Wales have received methoxyflurane analgesia, no case of renal failure following methoxyflurane analgesia has been treated in Cardiff, the only renal unit in the area. As the differences in the tests between the patients receiving methoxyflurane and those receiving nitrous oxide analgesia were not significant it may be concluded that methoxyflurane is not nephrotoxic when used as a self-administered obstetric analgesic.

We wish to thank Professor W. W. Mushin and Dr. W. W. Mapleson for much helpful advice. Mr. P. R. Allott carried out the statistical analyses with his computer programmes. We gratefully acknowledge the helpful co-operation of Dr. David Evans, our obstetric colleagues, and the midwives at the Maternity Hospital, Glossop Terrace, and St. David's Hospital, Cardiff. We also wish to thank Mrs. S. Chick and Mr. M. Shelley for technical help.

\section{References}

Committee on Anesthesia of National Academy of Sciences and National Research Council (1971). Anesthesiology, 34, 505.

Crandall, W. B., Pappas, S. G., and MacDonald, A. (1966). Anesthesiology 27,591 .

Eliahou, H. E., and Bata, A. (1965). Nephron, 2, 287.

Frascino, J. A., Vanamee, P., and Rosen, P. P. (1970). New England fourna of Medicine, 283, 676.

Hytten, F. E., and Leitch, I. (1964). The Physiology of Human Pregnancy. Oxford, Blackwell Scientific.

Jones, P. L., Rosen, M., Mushin, W. W., and Jones, E. V. (1969). British Medical fournal, 3, 259.

Lapointe, A., and Bele-Binda, N. (1970). Canadian Anaesthetists' Society fournal, 17, 145.

Latto, P., Rosen, M., and Molloy, M. J. (1972). British Fournal of Anaesthesia. In press.

Major, V., Rosen, M., and Mushin, W. W. (1966). British Medical fournal, $2,1554$.

Mazze, R. I., Shue, G. L., and Jackson, S. H. (1971). Fournal of the American Medical Association, 216, 278.

Perlmutter, M., Grossman, S. L., Rothenberg, S., and Dobkin, G. (1959).

Fournal of the American Medical Association, 170, 1533.
Rosen, M., Mushin, W. W., Jones, P. L., and Jones, E. V. (1969). British Medical fournal, 3, 263.

Vandam, L. D. (1970). New England fournal of Medicine, 283, 705. 